\title{
Michał Płóciennik
}

Uniwersytet Humanistyczno-Przyrodniczy im. Jana Długosza w Częstochowie ORCID 0000-0003-3644-0027

\section{Intratrynitarność Boga jako objawiony klucz hermeneutyczny chrześcijańsko-prawdziwościowej antropologii}

\author{
Myślę, że gdyby Bóg nie był Trójcą, \\ prawdopodobnie byłbym ateistą. [...] \\ W każdym razie, gdyby Bóg nie był Trójcą, \\ ja niczego bym już nie rozumiał ${ }^{1}$. \\ Trynitarne samoobjawienie Boga jest zatem \\ przewyższająca odpowiedzia na pytanie, które \\ człowiek nie tylko ma, lecz którym sam jest: \\ pytanie o Boga $a^{2}$.
}

\begin{abstract}
Abstrakt: Trójjedyność Boga jest treścią najważniejszego chrześcijańskiego dogmatu, będąc kluczem hermeneutycznym doświadczenia Objawienia i historii zbawienia. Stanowi ona jedną i w gruncie rzeczy jedyną Prawdę wielu prawd wiary. Doświadczeniem, które konstytuuje chrześcijaństwo, jest bowiem radykalne i definitywne samoudzielenie się Trójjedynego Boga - Pater per Filium in Spiritu Sancto. Dlatego zrozumienie, kim jest Trójjedyny Bóg, stanowi niezbywalny chrześcijańsko-prawdziwościowy warunek wszelkiej możliwej hermeneutyki. Nie chodzi tu jedynie o fascynującą spekulację, ale o być albo nie być chrześcijaństwa, a tym samym o być albo nie być ludzkości w jej całej stworzonej realności jako właściwego adresata samoudzielenia się Boga. Tajemnica każdego człowieka, zarówno w jego wymiarze indywidualnym, jak i społecznym, jest bowiem z chrześcijańskiej perspektywy dana do rozumienia jedynie jako wydarzająca się pomiędzy Ojcem, Synem i Duchem Świętym.
\end{abstract}

Słowa kluczowe: Trójca Święta, antropologia teologiczna, hermeneutyka trynitarna, samoobjawienie się Boga

1 F. Varillon, Radość wiary, radość życia, 140.

2 W. Kasper, Bóg Jezusa Chrystusa, 388-389 [kursywa oryginalna]. 
\iniejszy tekst stanowi próbę podjęcia i rozumiejącego rozjaś1 nienia, a także względnie ostatecznego ukierunkowania zagadnienia autopytajności-autoproblematyczności człowieka, a co za tym idzie, jego tożsamości, w perspektywie chrześcijańskiego klucza hermeneutycznego, jakim jest radykalne zbawcze samoudzielenie się Boga Ojca człowiekowi przez Chrystusa w Duchu Świętym. Składa się on z czterech części: (1) w pierwszej zostanie wyeksplikowany problem tożsamościowego zapytywania człowieka $i$ jego sprofilowania z perspektywy chrześcijańskiej odpowiedzi, (2) następnie wskażemy na misterium Trójjedynego Boga będące treścią owej odpowiedzi, (3) aby podkreślić najważniejsze implikacje wypływające z trynito-chrysto-logicznej tożsamości człowieka dla zrozumienia i przeżywania siebie w relacji do Boga, drugiego człowieka, siebie samego i kosmosu, (4) by ostatecznie dokonać próby podsumowania całości rozważań w formie dziesięciu tez.

Na wstępie niezbędne są dwie uwagi metodologiczne. Po pierwsze, tekst ten nie jest pisany z jakiegoś panoptikonu chrześcijańskiego, gdyż takowy nie istnieje poza chrześcijańskimi denominacjami (co nie znaczy, że wyczerpuje się w nich). Przyjmujemy zasadniczo rzymsko-katolicki punkt widzenia, uwzględniając przy tym inne chrześcijańskie ujęcia niektórych kwestii, zwłaszcza w myśli prawosławnej. Należy przy tym zauważyć, iż antropologia okazuje się być najprawdopodobniej przestrzenią najtrudniejszą ekumenicznie, gdyż w niej, jak w soczewce, skupia się cała problematyka teologiczna zakorzeniona w istotności religio, a więc siatce interakcji Trójjedynego Boga i człowieka, ludzi, świata. Świadczą o tym choćby próby budowania chrześcijańskiej antropologii w perspektywie ekumenicznej, wyrażające w pierwszej mierze taką potrzebę, a zarazem swoisty brak ${ }^{3}$.

Po drugie, tytułowy prawdziwościowy charakter chrześcijańskiej antropologii polega na tym, iż nie chce ona być w swej trynito-chrysto-(w Duchu)-źródłowości jedynie pewną propozycją - jedną z wielu - hermeneutyki ludzkiej bytowości w całej jej złożoności i wielokontekstowości. Rości sobie pretensje do bycia radykalnie

3 Zob. J. Bujak, Człowiek jako imago Dei; J. Bujak, „Czy istnieje możliwość”, 49-76; M. Składanowski, Niewiele mniejszy od aniołów. 
nieprzewyższalną, ostateczną i całościową - resp. inkluzywnie jedyną, choć pojmowalną jedynie w misterium niepojmowalności Boga, możliwością donacyjnego samorozumienia, samospełnienia ${ }^{4}$ człowieka. Ugruntowana jest na stwórczo-zbawczej nieodwołalności ruchu Boga ku niemu, będącego w całej rozciągłości zarówno docelowością (zbawienie jako uczestniczenie w życiu Boga) owego samorozumienia, samospełnienia, jak i transcendentalnym warunkiem jego możliwości (stworzenie jako powołaniowe ukierunkowanie na zbawienie), a także przestrzenią przebywania drogi pomiędzy nimi, z uwzględnieniem ewentualnych zawirowań (grzech - odkupienie).

\section{Autoproblematyczność 5 człowieka a tajemnica jego teo-ikoniczności}

Podstawowym warunkiem autentycznego przeżywania przez człowieka własnej egzystencji w jej wszystkich wymiarach interakcyjnych (z samym sobą, innymi ludźmi, szeroko rozumianym światem-kosmosem) jest zrozumienie samego siebie, odkrycie i rozpoznanie własnej tożsamości. Wiąże się z tym perspektywa możliwej samorealizacji i samospełnienia człowieka. Jednak owa tożsamość bytowa człowieka nie jest mu dana w bezpośrednim oglądzie, ale raczej zadana, a on sam doświadcza siebie jako wezwanego - powołanego do jej poszukiwania i odkrywania. Uświadamia on sobie siebie samego jako transcendentalnie otwartą pytajność, przekraczającą samą siebie we wszelkich kierunkach ontyczno-czasowych.

4 Przez samospełnienie człowieka, a w nim i poprzez niego, całego stworzenia rozumiemy osiągnięcie zamierzonej dla nich przez Boga pełni, stanu ostatecznego, a więc wiecznego uczestnictwa w wewnętrznym życiu Trójjedynego Boga. Mówiąc o samorozumieniu i samospełnieniu, nie mamy przy tym na myśli, iż jest to osiągalne jedynie własną mocą człowieka, gdyż jest ono dostępne w formie bezwarunkowego daru-łaski, który wymaga przyjęcia i dialogu, a przez to angażuje również do współdziałania, tak iż wewnątrz zawsze uprzedzającego daru Boga (człowiek i całe stworzenie są same dla siebie zawsze podstawowym Bożym darem w tym, że są i jakie są) można mówić o autorealizacji płynącej z łaski i wolności człowieka (i kosmosu), będącej najbardziej własnym aktem człowieka - por. R.J. Woźniak, Przyszłość, teologia, społeczeństwo, 32.

5 „I stałem się sam dla siebie wielkim problemem” - Augustyn z Hippony, Wyznania, IV, 4, 99. 
Ostatecznie owa otwartość autopytajności człowieka sprawia, że wszelkie pytanie, niezależnie od przedmiotu, ku któremu się kieruje i który je wywołuje, jest zapośredniczone i dochodzi do głosu w pytaniu, jakim jest człowiek sam dla siebie i jakim w człowieku jest cała rzeczywistość 6 . Transcendentalnie otwarta autopytajność nie stanowi zatem jakiejś przypadłościowości w ludzkiej egzystencji, nie jest luksusowym dodatkiem, możliwym do zignorowania, ale raczej jest właśnie transcendentalnym przed-założeniem tego, co istotnie ludzkie. Stąd ufundowane na owej autopytajności wydarzenie człowieka nie poddaje się reifikującej problematyzacji, stanowiąc nie problem, ale tajemnicę ${ }^{7}$.

Ostateczny sens, źródło i ukierunkowanie ludzkiego autopytajnego za-dania - wychylenia jako ,bycia na obraz i podobieństwo Boga", a więc capax Dei - możliwe są do rozjaśnienia - i z perspektywy chrześcijańskiej rozjaśnia się - jedynie jako adekwatny ruch hermeneutyczny, generująco-odsłaniający tożsamość człowieka w jej nieskończonej epektazie ${ }^{8}$. Ma on miejsce na horyzoncie bycia warunkowanym i wyznaczonym przez ,stwórczo-objawieniowe samokomunikowania się Trójjedynego Boga człowiekowi, rozpatrywanemu w swoim odniesieniu kosmicznym, zmierzającego przez Boże powołaniowo-zbawcze działanie przez Chrystusa w Duchu Świętym (w wyniku grzechu nabiera ono także charakteru odkupieńczego) ku eschatycznej «na zawsze», bosko-ludzko-kosmicznej wspólnocie

6 Por. J. Cuda, Wiarygodna antropologia, 17. „Wielcy mistrzowie powiadają, że najważniejsze pytanie na świecie brzmi: Kim jestem? Albo inaczej: czym jest «ja»? Czym jest to, co nazywam «ja»? Czym jest to, co nazywam sobą? Pojąłeś, czym jest świat, a nie zrozumiałeś tego kim jesteś. Rozumiesz astronomię, wiesz co to czarne dziury i kwazary, znasz informatykę, a nie wiesz kim jesteś. [...] Mówisz, że wiesz, kim jest Jezus Chrystus, a nie wiesz kim ty jesteś! Skąd wiesz, że zrozumiałeś Jezusa Chrystusa? Kim jest ta osoba, która twierdzi, że wszystko to pojęła? Spróbujmy wpierw na to pytanie odpowiedzieć. Czyż taka odpowiedź nie jest fundamentem wszystkiego?" - A. de Mello, Przebudzenie, 48.

7 Por. G. Marcel, Być i mieć, 117-119.

8 Epektaza oznacza nieustanne, nieskończone zdążanie do Nieskończoności - Absolutu/Boga - poprzez ciągłe przekraczanie siebie; termin ten jest kluczowy w myśli św. Grzegorza z Nyssy - zob. M. Manikowski, „Ekstasis i epektasis”, 71-86. 


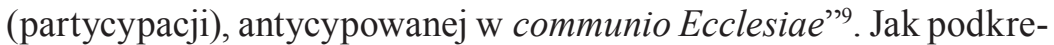
śla Jan Paweł II „to, kim jest człowiek i co powinien czynić, ujawnia się w momencie, gdy Bóg objawia samego siebie"10 jako Trójjedynego: Ojca przez Chrystusa w Duchu Świętym i ostatecznie o tyle, o ile Bóg w swej boskości jest właśnie Trójjedyny ${ }^{11}$, wszak jak pisze Włodzimierz Łosski - „to Jej [Trójcy - przyp. M.P.] poszukujemy, szukając Boga, szukając pełni bytu, sensu i celu istnienia. Pierwotne Objawienie i źródło wszelkiego objawienia, jak i wszelkiego bytu, Święta Trójca narzuca się naszej świadomości religijnej: należy to przyjąć jako fakt, którego oczywistość i konieczność może się opierać wyłącznie na nim samym"12. To tu właśnie lokuje się differentia specifica chrześcijańskiej antropologii - objawionej antropologii trynito-chrysto-logicznej ${ }^{13}$.

9 M. Płóciennik, Państwo Boże w relacji, 43-44. Owo samokomunikowanie, owszem przy zachowaniu absolutnej transcendencji i wolności Boga, wydarza się jednak ,wewnątrz” trynitarnych relacji. Więcej - niejako „na przedłużeniu” wewnątrzboskich pochodzeń, stąd uprawnione jest mówienie o chrześcijańskim, trynitarnym pa-en-teizmie - zob. M. Kehl, I widział Bóg, 341-353. Specyfiką chrześcijańskiego pojęcia Boga jest jednoczesność Jego trynitarnie rozumianej radykalnej transcendencji i radykalnej immanencji-zob. K. Rahner, O specyfice chrześcijańskiego, 157-167.

10 Jan Paweł II, Veritatis splenor, nr 10 [kursywa oryginalna].

11 „Nasza ludzka sytuacja, nasze myślenie i bycie, wszelkie bycie doświadcza zwrotu, jeśli Bóg jest Trójcą i jeśli jako Trójca ma swoją historię w naszej historii. Zwrot ten przekracza wszelkie «wniesione» przez człowieka wzorce myślenia o Bogu, o sobie, o świecie, o bycie. Nie wystarczy zwykła «relektura» przedrozumienia ontologii [antropologii - przyp. M.P.], wobec perspektywy jakie tu roztaczają się przed ludzkim bytem i rozumem. Potrzeba «nowej ontologii», «ontologii trynitarnej» [nowej antropologii, antropologii trynitarnej - przyp. M.P.] jest konsekwencją tej wiary" - K. Hemmerle, Tezy ontologii, 45. W innym miejscu Hemmerle mówi wręcz o rewolucyjnej przemianie rozumienia świata i człowieka, będącej konsekwencją rewolucyjnego obrazu Boga jakim jest Trójca - por. K. Hemmerle, Glauben, 147.

12 W. Łosski, Teologia mistyczna, 67.

13 Warto w tym miejscu stanowczo podkreślić, iż misteryjność Boskiej trójjedyności, pod warunkiem jej właściwej apofatycznie hermeneutyki, stanowi solidną relatywizację, jeśli nie wręcz, ,zaprzeczenie tezy Feuerbacha, że człowiek stworzył Boga na swój obraz i podobieństwo. Właśnie Bóg w Trójcy Świętej jedyny, to coś, co radykalnie odbiega od naszych wyobrażeń i obrazów, którymi się posługujemy. [...] Trójca Święta jest znakiem zarówno transcendencji Boga względem świata naszych pojęć, jak i niezależności Boga od wszelkich form ludzkiego 


\section{Trynitarna istotowość chrześcijaństwa jako Sitz im Leben objawionej antropologii}

Samorozumienie się chrześcijaństwa jest i zawsze było uczestniczącą próbą wniknięcia w wydarzenia je fundujące, których podmiotami byli Jezus z Nazaretu oraz przede wszystkim dwunastu Apostołów. Właściwie należałoby chyba mówić o jednym doświadczeniu, którego podmiotem był/jest Jezus (w wyniku Wcielenia w teandryczności swojego bytu), w swym odniesieniu do Boga, którego nazywał $A b b a$, w Duchu Świętym, a którego współuczestnikiem na mocy Misterium Paschalnego i Pięćdziesiątnicy, stała się wspólnota eklezjalna ${ }^{14}$. Jej misją jest aktualizowanie tego współuczestnictwa we wszystkich i wszystkim, zawsze i wszędzie aż do Jego wypełnienia się w Królestwie Niebieskim. Kościół długo i żmudnie dochodził do dyskursywnego i językowego wyrazu posiadanej implicite świadomości, iż novum-pełnia a zarazem ostateczność objawieniowo-soteryczna wydarzenia i Osoby Chrystusa, gwarantujące eschatyczne w jego ,już i jeszcze nie" zbawienie, nabudowane są na fakcie, że w Jezusie z Nazaretu Bóg utożsamił się z człowiekiem i podarował się mu całkowicie i definitywnie, „do końca” (por. J 13,1; Rz 8,32-39) w Duchu Świętym ${ }^{15}$. Podarował się takim, jakim jest sam w sobie, a więc jako

zaangażowania” - „Przepowiadanie Trójjedynego”, 17. Przy tym wszelkie analogie trynitarne (vestigia trinitatis) odkrywane zarówno w świecie przyrody, a także w człowieku, służące do przybliżenia dogmatu, nie stanowią żadnych naturalnych dowodów istnienia Trójcy, „nie są one żadna demonstracja, lecz raczej zakładającymi wyznanie wiary w Trójcę Święta późniejszymi ilustracjami” - W. Kasper, Bóg Jezusa, 337 [kursywa oryginalna].

14 Należy zawsze pamiętać o ontycznym pierwszeństwie bycia Bogiem Jezusa wobec kwestii i sposobu doświadczania tego przez Niego w swoim człowieczeństwie od momentu Wcielenia, a także komunikowania tegoż doświadczenia oraz udzielania w nim uczestnictwa, oraz o nigdy nieprzekraczalnym odróżnieniu Jednorodzonego Synostwa Jezusa, a więc Jego od zawsze Boskiego bytu, współistotności Ojcu i stworzonego z woli Bożej udziału człowieka i całego stworzenia w tymże Jedynym Synostwie jako ,synów w Synu”.

15 Wydarzenie Chrystusa ma miejsce w Duchu i dostęp do niego i uczestnictwo w nim jest możliwe tylko i wyłącznie w tymże Duchu. „Dlatego należy wciąż mieć na uwadze fakt, że zbawcze działanie Trójcy realizuje się w dynamice misterium paschalnego w trzech nierozdzielnych etapach: męka i śmierć Jezusa Chrystusa, Jego zmartwychwstanie i zesłanie Ducha Świętego. [...] Działanie Jezusa Chrystusa i działanie Ducha Świętego - «dwóch rąk Ojca» (św. Ireneusz) - musi być zawsze 
Ojciec, Syn i Duch Święty ${ }^{16}$. Stało się to możliwe w momencie odkrycia i rozpoznania w Duchu Świętym przez wiarę (por. 1 Kor 12,3) właściwego i ostatecznego podmiotu wydarzenia Chrystusa, którym jest Boska Osoba Syna, jednego z Trójcy, wszak ,ludzka natura Chrystusa należy na własność do Boskiej Osoby Syna Bożego, który ją przyjął [w akcie Wcielenia - przyp. M.P.]. Wszystko to, kim On jest, i to co czyni w niej pochodzi, pochodzi z «Jednego z Trójcy». Syn Boży udziela więc swojemu człowieczeństwu swojego osobowego sposobu istnienia w Trójcy. Zarówno w swojej duszy jak w swoim ciele Chrystus wyraża więc po ludzku Boskie życie Trójcy"17. Jednakże, zwłaszcza na płaszczyźnie praktyki inicjacyjnej i kultu, chrześcijaństwo od samego początku zdawało sobie sprawę, iż jego tożsamościowa istota znajduje się właśnie w owym samoudzieleniu się Boga - Ojca przez Syna w Duchu Świętym ${ }^{18}$. W wyniku autorefleksji chrześcijaństwa, a także z powodu pojawiania się poglądów kwestionujących i wypaczających to podstawowe doświadczenie tożsamościowe oraz z uwagi na wyzwania misyjne, Kościół podjął się próby precyzacji treści owego doświadczenia, odrzucając zarazem racjonalistyczne ataki na jego misteryjność w postaci herezji. Re-

splecione, bo jedno jest przez drugie oświetlone i jedno przez drugie się tłumaczy. [...] To właśnie «Duch Chrystusa» ożywia, jednoczy i rządzi Kościołem, bo jest to ten sam Duch, który obecny jest w Głowie i w członkach jako zasada jego życia. [...] Ojciec podejmuje inicjatywę i posyła. Syn wciela się i spełnia antropologiczne pośrednictwo jako ludzka istota w przestrzeni i czasie. Duch Święty zaś urzeczywistnia, personalizuje i interioryzuje zbawienie w każdej osobie, która Go przyjmuje w każdym czasie i każdym miejscu" - Papieska Rada ds. Krzewienia Nowej Ewangelizacji, Żyć rokiem wiary, 49-50. Jak wszelkie działanie polegające na samodarowaniu się Boga dokonuje się od Ojca przez Syna w Duchu Świętym, tak jego przyjęcie i wszelka odpowiedź człowieka przebiega wewnątrz tegoż boskiego działania - przez Chrystusa w Duchu Świętym ku Ojcu. Ową podwójną dynamikę (zstępującą i wstępującą) oddaje znakomicie doksologia eucharystyczna: „przez Chrystusa, z Chrystusem i w Chrystusie, Tobie Boże Ojcze wszechmogący, w jedności Ducha Świętego [...]".

16 Por. G. Greshake, Wierzę w Boga Trójjedynego, 15-24; K. Rahner, „Doświadczenia katolickiego teologa”, 75; J. Ratzinger, „Was ist für”, 11-19.

17 KKK nr 470.

18 Wedle genialnego sformułowania św. Cezarego z Arles „wiara wszystkich chrześcijan opiera się na Trójcy Świętej”, cyt za: KKK nr 232. Por. E. Piotrowski, Traktat o Trójcy Świętej, 61-65. 
fleksja przeniesiona z płaszczyzny soteriologicznego działania Ojca przez Syna w Duchu Świętym na płaszczyznę ontologiczną, której zalążki - tylko i jednocześnie aż zalążki - widziane zawsze w aspekcie zbawczym znajdujemy już w Nowym Testamencie ${ }^{19}$, doprowadziła do rozjaśnienia i zarazem zachowania tajemnicy Ojca, Syna i Ducha Świętego jako immanentnej i tożsamej z jednym-jedynym Bogiem ${ }^{20}$. Z czasem, choćby w schyłkowej scholastyce i nowożytności, dały o sobie znać niebezpieczeństwa takiego podejścia, kiedy to ontologiczna spekulacja przysłoniła charakter zbawczy dogmatu, czyniąc go praktycznie - duchowo i liturgicznie - niefunkcjonalnym, a więc w pewnym sensie nieobecnym - Bóg nie był postrzegany i przeżywany w swej Trójjedyności, która była w dodatku widziana jako zbędny, spekulatywny, „niezbawczy” balast ${ }^{21}$.

Bóg udziela się jako Ojciec, Syn i Duch Święty, bo w rzeczywistości od wieków jest Ojcem, Synem i Duchem Świętym - jeden Bóg w trzech Osobach - Trójca Święta! ${ }^{22}$ Oto co stanowi o istocie chrześcijaństwa jako specificum christianorum. To właśnie ten Trójjedyny

19 Por. Międzynarodowa Komisja Teologiczna, Teologia, chrystologia, antropologia, 137 (dalej MKT).

20 Swój normatywny i konstytutywny wyraz znalazło to zwłaszcza na dwóch pierwszych soborach - w Nicei w 325 r. i w Konstantynopolu w 381 r. - gdzie został ogłoszony ortodoksyjny paradygmat trynitarnego rozumienia Boga i Jego stwórczo-zbawczego actio; por. Breviarium Fidei, IX, 7.10 (dalej BF). Zob. J. Królikowski, Trójca Święta, 50-76.

21 Por. T. Dzidek, Granice rozumu, 211-212. W tym kontekście należy rozumieć słynną konstatację apraktyczności - zarówno poznawczej, jak i moralno-życiowej dogmatu trynitarnego I. Kanta (por. I. Kant, Streit der Fakultäten, 41). Z pewnością można, przynajmniej częściowo, oświeceniową i kantowską krytykę religii, w tym i trynitologii, obarczyć winą za marginalizację prawdy o Trójcy, co podkreśla L. Scheffczyk (por. L. Scheffczyk, Uneingelöste Traditionen der Trinitätslehre, 47), jednakże wydaje się, że Kant odzwierciedla także już zastany, ówczesny stan rzeczy.

22 Troistość Boga nie jest jakimś naddatkiem-przypadłością do Jego boskości, ale jest sposobem istnienia tejże boskości, będąc z nią tożsama. Kwestię relacji Osób Boskich do Boskiej natury rozstrzygnął Sobór Laterański IV, stwierdzając pełną tożsamość wszystkich Osób, jak i każdej z osobna, z naturą boską - por. Konstytucja O błędzie opata Joachima, nry 2, 4-7, w: Dokumenty Soborów Powszechnych, t. II. W tym duchu H.U. von Balthasar stwierdza: „Die Natur Gottes ist es, Trinität zu sein" - H.U. von Balthasar, Theologik, B. III, 49. 
Bóg był/jest treścią doświadczenia-wydarzenia człowieka Jezusa z Nazaretu (które było/jest ludzką eksplikacją bycia Synem drugiej Osoby Boskiej) w Duchu Świętym ${ }^{23}$ (przez samego Jezusa jak i przez uczniów, gdyż doświadczenie to dane jest jedynie w przestrzeni wiary), jako definitywnie zbawczej interakcji Boga z człowiekiem i światem, a które w sposób anamnetyczno-epikletyczny przeżywane jest w Kościele, aż do jego eschatycznego spełnienia w Królestwie Niebieskim ${ }^{24}$. Innymi słowy, nie gdzie indziej, jak „w wewnętrznym życiu Boga trynitarnego istnieje warunek możliwości tych wydarzeń, które dzięki niepojętej wolności Boga zostają nam ofiarowane w historii zbawienia przez Pana Jezusa Chrystusa"25. Więcej:

[...] to wydarzenie, w którym Bóg objawia i komunikuje się w sposób absolutny i definitywny, dotyczy jakoś własnego bytu Boga Ojca, o ile jest Bogiem, który wypełnia te misteria i żyje nimi jako swoimi w zjednoczeniu z Synem i Duchem Świętym. Nie tylko bowiem w misterium Jezusa Chrystusa Bóg Ojciec objawia się i komunikuje nam w sposób wolny i darmowy za pośrednictwem Syna i w Duchu Świętym, ale Ojciec z Synem i Duchem Świętym prowadzi życie trynitarne

${ }^{23}$ Por. G. Greshake, Trójjedyny Bóg, 44-47. W tym kontekście R.J. Woźniak mówi o dynamiczno-funkcjonalnym chrystocentryzmie, w przeciwieństwie do redukcjonistycznego chrystomonizmu, ufundowanym i spełniającym się w szerszej perspektywie trynitarnej - trynitarnego planu stworzenia-zbawienia - por. R.J. Woźniak, Chrystocentryzm teologii chrześcijańskiej, 367-394. Zob. także J. Dupuis, Chrześcijaństwo i religie, 134-144.

24 „Tajemnica Trójcy Świętej jest centralną tajemnicą wiary i życia chrześcijańskiego. Jest tajemnicą Boga w sobie samym, a więc źródłem pozostałych tajemnic wiary oraz światłem, które je oświeca. Tajemnica ta jest najbardziej podstawowym $\mathrm{i}$ istotnym nauczaniem $\mathrm{w}$ «hierarchii prawd» wiary. «Historia zbawienia nie jest niczym innym, jak historią drogi i sposobu, przez które prawdziwy i jedyny Bóg, Ojciec, Syn i Duch Święty, objawia się, pojednuje i jednoczy ze sobą ludzi, odwróconych od grzechu»" - KKK nr 234. W Niemieckim Katechizmie dla Dorosłych (Katholischer Erwachsenen-Katechismus, Band 1: Das Glaubensbekenntnis der Kirche) czytamy zaś: „Aus diesem Ursprung geht hervor, daß das Bekenntnis zum dreifaltigen Gott die Summe des christlichen Glaubens ist”, za: www.alt.dbk.de/ katechismus/index.php, 84 (dostęp 10.08.2021).

25 MKT, 139. 
w najgłębszy sposób i - przynajmniej według naszego sposobu myślenia - w jakiś nowy sposób, o ile relacja Ojca do wcielonego Syna w wypełnieniu daru Ducha Świętego jest samą konstytutywną relacją Trójcy ${ }^{26}$.

Owo historycznie uwarunkowane, a mimo to właśnie w tejże historyczności pełne i ostateczne samoobjawienie się $\mathrm{Boga}^{27}$, staje się tym samym objawieniem człowieka i całej rzeczywistości stworzonej im samym ${ }^{28}$, w nich samych - w samym sercu ich historyczności ${ }^{29}$ a ich misteryjność okazuje się być od początku obecną, choć zakrytą, partycypacją w Mysterium Trinitatis.

Spodobało się Bogu, w swej dobroci i mądrości objawić samego siebie i ukazać tajemnicę swej woli (por. Ef 1,9), dzięki której ludzie przez Chrystusa, Słowo, które stało się ciałem, mają dostęp do Ojca w Duchu Świętym [tak i tylko tak przebiega ostatecznie wszelka relacja Boga z człowiekiem i ludzka

26 MKT, 138-139.

27 Por. Dei Verbum, nry 3-4 (dalej DV). Teksty soborowe przywołuję za: Sobór Watykański II. Konstytucje, Dekrety, Deklaracje, Poznań 2002; Kongregacja Nauki Wiary, Deklaracja Dominus Iesus, nry 5-8, Poznań 2000.

${ }^{28}$ „W istocie misterium człowieka wyjaśnia się prawdziwie jedynie w misterium Słowa Wcielonego. Adam bowiem, pierwszy człowiek, był typem Tego, który miał przyjść, to znaczy Chrystusa Pana. Chrystus, nowy Adam, właśnie w objawieniu tajemnicy Ojca i Jego miłości objawia w pełni człowieka samemu człowiekowi i odsłania przed nim jego najwyższe powołanie. Nic więc dziwnego, że wspomniane prawdy w Nim mają źródło i w Nim osiągają punkt szczytowy. Ten, który jest «obrazem Boga niewidzialnego» (Kol 1,15), jest zarazem doskonałym człowiekiem, który przywrócił synom Adama podobieństwo Boże, zniekształcone przez grzech pierworodny. Ponieważ w Nim natura ludzka została przyjęta, a nie odrzucona, tym samym także w nas została wyniesiona do wysokiej godności. On sam bowiem, Syn Boży, poprzez wcielenie zjednoczył się w pewien z każdym człowiekiem" - Gaudium et spes, nr 22 (dalej GS). Por. Jan Paweł II, Redemptor hominis, nry 8-14 (dalej RH). W tym miejscu konieczne jest podkreślenie chrysto-logicznego, czy wręcz chrysto-telicznego wymiaru ludzkiej teo-ikoniczności i kwestia chrystomorfizacji - por. A. Scola, G. Marengo, J.P. López, Osoba ludzka, $145-157$.

${ }^{29}$ Por. Jan Paweł II, Fides et ratio, nry 10-12 (dalej FR); Jan Paweł II, Novo millennio ineunte, $\mathrm{nr} 5$ (dalej NMI). 
relacja religijna z Bogiem, co nie oznacza, że zawsze w sposób świadomy - przyp. M.P.] i stają się współuczestnikami Bożej natury (por. Ef 2,18; 2 P 1,4). Przez to objawienie niewidzialny Bóg (por. Kol 1,15; 1 Tm 1,17) w swojej wielkiej miłości przemawia do ludzi jak do przyjaciół (por. Wj 33,11; J 15,14n) i przestaje z nimi (por. Ba 3,38), aby zaprosić i przyjąć ich do wspólnoty z sobą. Ta ekonomia Objawienia realizuje się przez czyny i słowa wewnętrznie ze sobą połączone, tak że czyny dokonane przez Boga w dziejach zbawienia ujawniają i potwierdzają doktrynę i sprawy wyrażone w słowach, słowa zaś obwieszczają czyny i rozświetlają zawartą w nich tajemnicę. Przez to Objawienie najgłębsza prawda zarówno o Bogu, jak i o zbawieniu ludzi jaśnieje dla nas w Chrystusie, który jest zarazem Pośrednikiem i Pełnią całego Objawienia (por. Mt 11,27; J 1,14.17; 14,6; 17,1-3; 2 Kor 3,16; 4,6; Ef 1,3-14) ${ }^{30}$.

A zatem tajemnica człowieka, jak i tajemnica całości stworzenia okazuje się mieć swój topos w trynitarnym Bogu, w Jego intratrynitarnym życiu, lepiej: w relacyjnej strukturze jedności i inności Ojca, Syna i Ducha Świętego ${ }^{31}$. W niej bierze początek i do niej ostatecznie zmierza, i to począwszy od creatio $^{32}$ przez historię zba-

30 DV nr 2. Por. FR nry 7, 80; NMI nry 21-23.

31 Człowiek w swej apofatycznej misteryjności staje się/jest synowskim (,syn w Synu") wydarzeniem w intratrynitarnośc Boga, usytuowanym w zapośredniczeniu czasowo-historycznym eschatycznie w Chrystusowym byciu z/od Ojca ku/dla Ojcu w Duchu Świętym.

32 Por. A. Scola, Osoba ludzka, 71-81. Św. Jan od Krzyża w Romancy o Trójcy Przenajświętszej interpretuje stworzenie człowieka i świata w kategoriach wzajemnego daru Ojca i Syna w Duchu Świętym (por. A. Scola, Dzieła, 65-76; podobnie rzeczywistość Eschatonu ujmuje H.U. von Balthasar - por. Theodramatik IV, 476). Absolutnie wolny charakter aktu stwórczego szczęśliwego i doskonałego z samego siebie Boga, wyklucza funkcjonalne istnienie człowieka na modłę heglowską por. BF V, 18-19, 24-25, wskazując raczej na fakt, że człowiek, owszem, jak inne stworzenia powstał „dla chwały Bożej” (KKK nry 293-294), zarazem jako „będący jedynym stworzeniem, którego Bóg chciał ze względu na nie samo” (GS nr 24) został w Chrystusie stworzony-wybrany przez Boga i z miłości przeznaczony dla Niego samego („dla siebie”) jako przybrany syn „w/przez” Jezusa Chrystusa - por. Ef 1,4-5. 
wienia (i odkupienia) a na Eschatonie skończywszy ${ }^{33}$. W nią jest wciągnięta, czy też raczej nieustannie coraz bardziej wciągana ${ }^{34}$, w swym wspólnotowym powołaniu na wzór Trójcy (imago Trinitas) ${ }^{35}$ jako wołający w Duchu: Abba, Ojcze „synowie w Synu”36, żyjący z Trójcą, przez Trójcę, dla Trójcy i w Trójcy ${ }^{37}$. Innymi słowy, ,„przez bieg dziejów świata Trójca Święta prowadzi nas do Trójcy Świętej”38, do eschatologicznej (w absolutnie nieskończonej przyszłości) rewelatywnej aktualizacji trynito-chrysto-logicznej tożsamości naszego człowieczeństwa-ludzkiej natury w wielości ludzkich hipostaz na podobieństwo Trójcy przez partycypację w Jej szczęśliwości. Dobrze te kwestie podsumowuje R.J. Woźniak:

Trójjedyny Bóg żyjąc poza historią i światem rzeczywiście wydarzył się w historii. Zatem historia nie jest obca Bogu. W momencie wcielenia umocniła się bowiem jej więź z Bogiem i Boga z nią, dzieło stworzenia zostało dopełnione i ukoronowane. Prawdę tę uświadamia nam ze zdwojoną mocą fakt, iż Syn Boży jest już na zawsze człowiekiem. Osobowe zjednoczenie (unio hypostatica), które dokonało się w osobie Syna jest węzłem jedności Boga $\mathrm{z}$ historią i zanurzonymi w niej ludźmi wszystkich czasów. [...] Wydarzenie wcielenia lokując się w tajemnicy stworzenia sprawia również, iż tajemnica Boga i tajemnica człowieka są ze sobą już na zawsze nierozerwalnie powiązane: nie ma już Boga bez człowieka (Chrystus na zawsze jest człowiekiem) jak i nie ma człowieka bez Boga; nie ma już poznania Boga bez poznania człowieka jak i poznania człowieka bez poznania Boga. Bóg jest nieodwołalnie

33 Por. KKK nr 1024. Por. także B. Forte, Trójca Święta jako historia, 290-301; G. Greshake, Życie silniejsze niż śmierć, 113-120.

${ }_{34}$ Por. KKK nr 260. Por. także G. Greshake, Wierzę w Boga Trójjedynego, 53-59.

35 Por. GS nr $24 n$.

36 Por. GS nr 22.

37 Por. P. Krill, Life in Trinity.

38 M.M. Philipon, Trójca Święta w moim życiu, 230. Można mówić w związku z tym o triadoarchizmie, triadiocentryzmie i triadofinalyzmie - por. W. Misztal, Duchowość chrześcijan, szczególnie 63-83, 387-393. 
Bogiem z nami, człowiek zaś nie może być jak i nie może zostać pojęty bez Boga i jego wydarzenia się w historii. Nowe przymierze jest nieodwołalne. Jego gwarantem jest Jedyny Syn Ojca posyłający swego Ducha ${ }^{39}$.

Ów Jedyny Syn wcielony, na mocy nieodwołanej „,na zawsze” unii hipostatycznej, sam w sobie jest Nowym Przymierzem - Emmanuelem, gdyż zostało ono zawarte nie tylko przez Niego, ale dosłownie w Nim! W jedności Jego bytu i funkcji-misji, w której ,bycie dla siebie” staje się ,byciem dla innego" i ,byciem z innym”. Przez Niego i w Nim Bóg dokonuje ,już” pneumatologicznej aplikacji owego przymierza w sakramentalnym zapośredniczeniu swojego Kościoła ${ }^{40}$. Tenże w Nim samym mocą obecności Jego Ducha stanowi „niejako sakrament, czyli znak i narzędzie wewnętrznego zjednoczenia z Bogiem i jedności całego rodzaju ludzkiego"41 w funkcji ,jeszcze nie" Królestwa Bożego jako spełnionej bosko-ludzkiej communio ${ }^{42}$. Ostateczne objawienie człowieka samemu człowiekowi, a raczej jego ostateczna eksplikacja i ujawnienie obecne w Chrystusie, tożsame z jego samospełnieniem nastąpi w wyniku spotkania człowieka z Ojcem przez Chrystusa w Duchu Świętym „twarzą w twarz” (1 Kor 13,12)

39 R.J. Woźniak, Przyszłość, teologia, społeczeństwo, 38-39. Por. R.J. Woźniak, „Metafizyka i Trójca”, 293-294. Por. także G. Greshake, Trójjedyny Bóg, 268-289, zwł. 282-289. Owo Boskie bycie z nami jest niczym innym, jak wydarzeniem bycia w świecie wewnątrztrynitarnego życia, na mocy którego świat staje się byciem w intratrynitarności Boga, co znakomicie eksponuje Greshake - por. G. Greshake, Trójjedyny Bóg, 62-64. Z kolei Grzegorz Strzelczyk, akcentując realizm historyczności Wcielenia, zauważa, iż ,transcendentny Bóg wszedł w ludzką historię w taki sposób, że jako konkretny człowiek - Jezus z Nazaretu - stał się aktywnym podmiotem wpływającym na jej bieg, przy czym akty tego człowieka były «ludzką wersją» (od)-wiecznego stosunku Boga [Boskiej Osoby Syna w Jej odniesieniach do Ojca i Ducha, wszak to Ona była/jest podmiotem wydarzenia Chrystusa - przyp. M.P.] do świata i ludzi” - G. Strzelczyk, Teraz Jezus, 104.

40 W Chrystusie człowiek jako, ,syn w Synu” zostaje w pełni i na zawsze, choć ,jeszcze" w medium ,wiary, a nie widzenia” w sakramentalności Eklezji, w Duchu Świętym ukierunkowany ku Ojcu, stając się w wierze, nadziei i miłości ,jednym” w „Jednym z Trójcy”, co znakomicie obrazuje ikona Trójcy Świętej Rublowa w postaci pustego, bo przeznaczonego dla człowieka, miejsca przy stole Trzech.

41 Lumen gentium, nr 1 (dalej LG).

42 R.J. Woźniak, Przyszłość, teologia, społeczeństwo, 39-41. 
jako finalnym upodobnieniu przez Boski Archetyp człowieka do samego siebie (por. $1 \mathrm{~J}$ 3,2), przez co Bóg będzie ,wszystkim we wszystkich/wszystkim" (1 Kor 15,28) ${ }^{43}$.

\section{Trynito-chrysto-logicznie ugruntowana antropologia}

Jak zauważa Walter Kasper, ,trynitarne communio - jedność ukazuje się na drodze analogii jako model chrześcijańskiego rozumienia rzeczywistości" ${ }^{44}$. Jako klucz, ale nie inaczej, jak na drodze analogii! 45 Owa analogiczność jest konsekwencją niewyczerpywalności intratrynitarnej nieskończoności Boga w Jego ekonomicznym samoudzieleniu się, ze względu na: a) łaskawo-wolne, a nie koniecznościowe,

43 W owym eschatycznym spotkaniu spełnieniowym zbawieni nie tylko nie tracą swojej stworzonej tożsamości, ale „zachowują i - co więcej-odnajdują tam swoją prawdziwą tożsamość, swoje własne imię", KKK nr 1025. Przy czym tego eschatycznego stanu spełnienia nie należy rozumieć w kategoriach reifikująco-statycznych, ale personalistyczno-dynamicznych w horyzoncie infinitywnego spełniania w Bogu, tj. nieskończonego zdążania do już osiągniętej pełni-Boga (ze względu na niewyczerpywalność i nieskończoność Boga!), co znakomicie eksplikuje myśl św. Grzegorza z Nyssy - por. W. Szczerba, „Problem przebóstwienia”, 283-299.

44 W. Kasper, Bóg Jezusa, 384.

45 Analogia jest przestrzenią, w której dokonuje się Objawienie, lepiej: sposobem jego dokonywania się, a więc udzielania się tego, co boskie temu, co nie-boskie, który kulminuje w pełnej analogii-analogicznej pełni, którą jest Wcielony Syn Boży, zmierzającemu do eschatycznego najściślejszego zjednoczenia między Stwórcą a stworzeniem wewnątrz zachowania ich nieskończonej różnicy i odrębności. „Bóg w swojej samopoświęcającej się i rozlewającej się miłości objawia całkowitą odmienność swojego Bożego istnienia, a jednocześnie jest bliski bliskością największą z możliwych. I tak, możemy uzupełnić i rozwinąć zacytowany już wcześniej aksjomat Soboru Laterańskiego IV [idzie o następujące sformułowanie: ,[...] ponieważ między Stwórcą a stworzeniem nie można dopatrzeć się tak wielkiego podobieństwa, żeby nie trzeba było widzieć większej pomiędzy nimi różnicy" [Konstytucja $O$ błędzie..., nry 2, 7 - przyp. M.P.]. Chodzi nie tylko o to, że każdemu podobieństwu odpowiada jeszcze większe niepodobieństwo, lecz także o to, że również każdemu niepodobieństwu odpowiada jeszcze większe podobieństwo i bliskość z Bogiem, a nawet intymna relacja z Nim, bycie w Nim" - W. Kasper, Miłosierdzie, 108-109. W przypisie Kasper konstatuje, iż obydwa wymiary analogii są komplementarne, o ile pierwszy dotyczy porządku natury, a drugi porządku łaski - por. W. Kasper, Miłosierdzie, 254. Zob. P. Liszka, Analogia w teologii. 
samoudzielenie się Trójcy w historii, b) kenotyczny charakter tego samoudzielenia ${ }^{46}, \mathrm{c}$ ) uwarunkowania dzieła stworzonego, w ramach których dokonało się objawieniowe Wcielenie Jednego z Trójcy ${ }^{47}$. Dlatego niezbędne jest ,rozróżnienie «Trójcy immanentnej» i «Trójcy ekonomicznej» [które - przyp. M.P.] nie narusza ich rzeczywistej tożsamości”, gdyż z jednej strony „nie jest prawdą, że Trójca ukonstytuowała się dopiero w historii zbawienia [...]", z drugiej zaś strony, mimo iż „Bóg jest większy od tego wszystkiego, co możemy o Nim wiedzieć, to objawienie chrześcijańskie zapewnia nas, że to co «większe» ma zawsze charakter trynitarny"48.

Ostatecznie wszystko przeniknięte jest ową boską trynitarnością. Jak zauważa Łosski, idąc za Pawłem Florenskim, „dla myśli ludzkiej, jeśli chce odnaleźć doskonałą równowagę, nie ma innego wyjścia jak uznać antynomię trynitarną, bowiem odrzucając Trójcę jako jedyną podstawę wszelkiej rzeczywistości, wszelkiej myśli, wkracza się na drogę bez wyjścia, dochodzi do aporii, do obłędu, do rozdarcia bytu, do śmierci duchowej. Nie ma trzeciej drogi między Trójcą a piekłem”, mimo że „tak naprawdę, dogmat trynitarny jest krzyżem dla ludzkiej myśli” i to krzyżem apofatycznym, będącym poza wszelką myślą filozoficzno-spekulatywną ${ }^{49}$. „Oto wreszcie dlaczego objawienie

46 Por. W. Kasper, Bóg Jezusa, 341-342. „Bóg wydarza się w historii tylko dlatego, iż przed-historycznie wydarza się sam w sobie. Jego samo-wy-darzenie, jego wewnętrzne trynitarne bycie, jest historią przed wszelką historią, to znaczy zawsze już wyprzedza i ontologicznie przekracza tajemnice świata, nawet wtedy, kiedy w nim nieodwołalnie zamieszkuje. Bóg trynitarny wydarzając się w świecie i w jego historii jest wolny od owego świata i jego historii, właśnie dlatego, iż już zawsze uprzednio wydarza się sam w sobie" - R.J. Woźniak, Metafizyka i Trójca, 295.

47 Por. Y. Congar, Wierzę w Ducha Świętego, 35.

48 MKT, 138. Kasper konstatuje, iż ,właśnie w wydarzeniu Chrystusa nie może pozostać jakiekolwiek ciemne miejsce dla Deus absconditus «za» Deus revelatus. Raczej Deus revelatus jest Deus absconditus; nie do uchylenia tajemnica jest tajemnicą naszego zbawienia. [...] Ukazać łaskawo-wolny i kenotyczny charakter Trójcy ekonomicznej oznacza jednocześnie wyakcentować apofatyczny charakter Trójcy immanentnej, to znaczy charakter wymykający się wszelkiemu językowi i myśleniu. Jest Ona i pozostanie w (nie: za) Trójcy ekonomicznej mysterium stricte dictum", W. Kasper, Bóg Jezusa, 339.342.

49 W. Łosski, Teologia mistyczna, 67. Por. P. Florenski, Filar i podpora prawdy, 47-60. 
Trójcy jaśnieje w Kościele jako dana czysto religijna, jako prawda powszechna par excellence" ${ }^{50}$, a jako że „ostateczne powołanie człowieka jest w istocie jedno, mianowicie Boskie"51, uczłowieczenie tożsame jest z przebóstwieniem ${ }^{52}$, będącym w gruncie rzeczy ,trynitaryzacją" (G. Greshake) ${ }^{53}$, a więc definitywnym przebywaniem Ojca i Syna i Ducha Świętego w człowieku a człowieka w Bogu. Wzorcowym opisem owej bosko-ludzkiej(-kosmicznej) communio jest arcykapłańska modlitwa Chrystusa ${ }^{54}$ (J 17; zob. także 1 Kor 15,20-28 oraz Ap 20-22). Zatem, teo-antropologia chrześcijańska jest speiczną eschatologią, jako że

[...] to właśnie w niej prawda objawienia [objawionej teo-antropologii - przyp. M.P.] nabiera ostatecznego sensu, ujawniając radykalne zwrócenie się Trójjedynego Boga w stronę człowieka. Zwrócenie to przekracza perspektywę czasu, chociaż nieustannie jest w niej zakorzenione, i jest wybitnie eschatologiczne. Zaangażowanie Trójjedynego w dzieje świata i człowieka posiada wybitnie eschatologiczną perspektywę. Tajemnica wejścia Boga w historię jest zapowiedzią i obietnicą

50 W. Łosski, Teologia mistyczna, 68.

51 Por. GS nr 22. Jedność Boskiego powołania wszystkich ludzi implikuje, iż „odnosi się to nie tylko do chrześcijan, lecz także do wszystkich ludzi dobrej woli, w których sercu działa łaska. Skoro bowiem Chrystus umarł za wszystkich [...] powinniśmy utrzymywać, że Duch Święty wszystkim daje możliwość uczestniczenia w tym misterium paschalnym w tylko Bogu znany sposób" - GS nr 22. Teo-antropologia chrześcijańska nie ma zatem nic z ekskluzywizmu, ale na mocy powszechności zbawczej woli Boga i jedności Boskiego powołania wszystkich ludzi, jawi się jako trynito-chrysto-inkluzywna - por. m.in. Nostra aetate, nr 2, LG nr 16, Ad gentes, nry 3, 9.

52 Por. W. Hryniewicz, Chrystus nasza Pascha, 412-422. Zob. także K. Gryz, Antropologia przebóstwienia.

53 Stąd wszelkie antropologie ateistyczne jawią się jako w gruncie rzeczy a-ludzkie - wszak w Chrystusie najbardziej ludzki okazuje się być sam Bóg - prowadzą do tragedii i nie mają racji bytu, gdyż Bogiem człowiek może i powinien stać się ostatecznie dzięki Bogu i w Bogu, a nie w sposób autonomiczny i bez-bożny - co nie jest niczym innym jak istotą grzechu (por. Rdz 3) - por. G. Greshake, Trójjedyny Bóg, 475-476. Zob. także m.in. H. de Lubac, Dramat humanizmu ateistycznego; H. de Lubac, Ateizm i sens człowieka,; Od „śmierci Boga” do „śmierci człowieka”.

54 Por. R.J. Woźniak, Przyszłość, teologia, społeczeństwo, 28-30. 
wejścia człowieka w życie wieczne, jakim jest trynitarna perychoreza życia i miłości w wolności. Bez eschatologicznej perspektywy spełnionej obietnicy żadne z twierdzeń [...] [teo-antropologii - przyp. M.P.] nie ma sensu i pozostaje pozbawione swej istotnej treści ${ }^{55}$.

Analogicznie trynitarne rozumienie człowieka i rzeczywistości okazuje się być niczym innym jak odsłonięciem konstytutywnie komunijnego sensu bycia ${ }^{56}$ jako przyjmowania i dawania, jedności w różnorodności i różnorodności w jedności, wykraczającego poza skrajności ,jedności” i ,wspólnoty” ${ }^{\text {57 }}$.

Tu dotykamy istotnej różnicy, stwierdza Świderkówna: ,jedność” to zlanie się, ,wspólnota” zaś kojarzy się nam z jakąś grupą ludzi, która żyje ze sobą gorzej lub lepiej, niemniej stanowi wspólnotę. [...] Komunia to taka wspólnota- niestety nie ma innego słowa, by oddać tę więź- gdzie każdy, kto do niej należy może powiedzieć do drugiego: wszystko, co moje, twoje jest, a co twoje-moje (J 17,10). Przy czym „wszystko” oznacza nie tylko wszystko, co mam, ale przede wszystkim

55 R.J. Woźniak, Przyszłość, teologia, społeczeństwo, 11-12.

56 „W ten sposób wierzący stwierdza, że centrum istnienia, najgłębszą tajemnicą wszystkiego jest Boska komunia. [...] ten Bóg-komunia, wzajemne darzenie się miłością Ojca i Syna w Duchu Świętym, jest zdolny ogarnąć historię człowieka i wprowadzić go w swoją dynamikę komunii, mającą w Ojcu swój początek i swój ostateczny cel. [...] Wszystkie prawdy, w które wierzymy, mówią o tajemnicy nowego życia wiary jako drodze komunii z Bogiem żywym" - Franciszek, Lumen fidei, $\mathrm{nr} 45$.

57 W trynitarnym ugruntowaniu przekraczania skrajności, ,jedności” i ,wielości”, „tożsamości” i ,inności”, zapodmiotowana jest tajemnica absolutnej „inności”, „niepowtarzalności”, będąca, wydaje się, w postaci koncepcji osoby niekwestionowanym wkładem chrześcijaństwa w dzieje myśli ludzkiej, a jednocześnie właściwa hermeneutyka trójjednych interakcji Boga z człowiekiem i ze światem, gwarantująca im zachowanie własnej odrębności, przy jednoczesnym spełnieniu w Bogu - inność człowieka-świata w ich stworzoności w każdym etapie ich istnienia, włącznie z doświadczeniem mistycznym, gwarantowana jest obecnością „Innego” w Trójinnym Bogu! Owo Boskie ugruntowanie ,inności” w przestrzeni stworzonej szczególnie, choć oczywiście w sposób analogiczny, dotyczy człowieka, jako że każdy człowiek w swej teo-ikoniczności jest quasi-absolutnie ,,inny”, „niepowtarzalny”. 
to, czym jestem. To jest właśnie komunia. To wzajemne całkowite dawanie i przyjmowanie [...] że jest pełnią dawania i przyjmowania, przyjmowania i dawania. Teologowie greccy określili to mianem perichoresis ${ }^{58}$.

Ugruntowaniem komunii jest miłość ${ }^{59}$, bo Bóg jako trynitarna com-

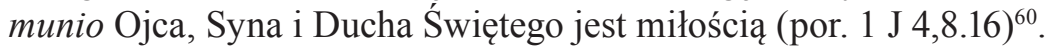
Dlatego właśnie człowiek, stworzony na „obraz i podobieństwo” miłosnej komunii Trójcy, jako JA=MY, ,nie może się w pełni odnaleźć inaczej, jak tylko przez szczery dar z samego siebie"61 jako sposobie partycypacji w życiu swego Archetypu, będącego JA=MY,

58 Od bogów pogańskich do Boga żywego, 80-81. Na temat perychorezy intratrynitarnej - zob. E. Piotrowski, Traktat o Trójcy Świętej, 267-268. Należy przy tym stanowczo podkreślić, iż ,Trynitarna communio-jedność różni się zasadniczo przez to od communio-jedności pomiędzy ludźmi, że jest w jednej i tej samej istocie, a nie tylko we wspólnocie różnorakich istot” - W. Kasper, Bóg Jezusa, 381, co zostało usankcjonowane w soborowym orzeczeniu przeciwko nauce Joachima z Fiore, nierozróżniającej boskiego i ludzkiego sposobu istnienia wspólnoty - por. Konstytucja o wierze, nry 2, 7.

59 Wszak miłość zakłada jednoczesną jedność i rozróżnienie-zróżnicowanie por. B. Forte, Trójca Święta jako historia, 145-154.

${ }^{60}$ Agapetologiczny model ujmowania-rozumienia bytowania Trójjedynego Boga, mimo związanych z nim aporii, a także różnych interpretacji w ramach poszczególnych systemów teologicznych, pozostaje mimo wszystko modelem względnie najbardziej adekwatnie przybliżającym Mysterium Trinitatis z racji na swe bycie usankcjonowanym natchnioną Boską autoegzegezą, daną w wydarzeniu się Boga w świecie w zapośredniczeniu stworzonych uwarunkowań jako przestrzeni odsłaniająco-zasłaniającej symboliczności, bo „miłość jest z Boga”- por. F. Drączkowski, Miłość synteza chrześcijaństwa. Podkreślmy jednakże, iż z chrześcijańskiej perspektywy odwrócenie stwierdzenia „Bóg jest miłością” w kierunku „miłość jest Bogiem”, możliwe jest jedynie na bazie tego pierwszego. Ciekawy model (!) uzasadniający istnienie w Bogu właśnie trójjedyność Boga (Trzy Osoby, oczywiście w sensie analogicznym w kontekście absolutnej inności każdej „Osoby” i pozaliczbowego bycia Boga! - Ojcowie Kościoła mówili o tajemnicy „3” jako wskazującej wykraczanie poza jedność - „1" i wielość „2”) z perspektywy miłości i jej wymogów, podaje Ryszard ze św. Wiktora - por. G. Greshake, Trójjedyny Bóg, 91-97.

${ }^{61}$ GS nr 24. 
zapośredniczanego, realizowanego i urzeczywistnianego antycypacyjnie w JA=MY Kościoła ${ }^{62}$. Jan Paweł II stwierdza dobitnie:

[...] człowiek nie może żyć bez miłości. Człowiek pozostaje dla siebie istotą niezrozumiałą, jego życie jest pozbawione sensu, jeśli nie objawi mu się Miłość, jeśli nie spotka się z Miłością, jeśli jej nie dotknie i nie uczyni w jakiś sposób swoją, jeśli nie znajdzie w niej żywego uczestnictwa. I dlatego właśnie Chrystus-Odkupiciel, [Jeden z Trójcy w swej ziemskiej wersji Synowskiego odniesienia do Ojca i Ducha - przyp. M.P.] [...] „objawia w pełni człowieka samemu człowiekowi”. To jest ów - jeśli tak wolno się wyrazić - ludzki wymiar Tajemnicy Odkupienia [zespolony nierozdzielnie i zapodmiotowany z/w Boskim wymiarze Tajemnicy Odkupienia w Jezusie Chrystusie jako imieniu objawiającym miłość miłosierną; $\mathrm{RH}$ nr 9 - przyp. M.P.]. Człowiek odnajduje w nim swoją właściwą wielkość, godność i wartość swego człowieczeństwa. [...] Człowiek, który chce zrozumieć siebie do końca - nie wedle jakichś tylko doraźnych, częściowych czasem powierzchownych a nawet pozornych kryteriów i miar swojej własnej istoty - musi ze swoim niepokojem, niepewnością, a także słabością i grzesznością, ze swoim życiem i śmiercią, przybliżyć się do Chrystusa. Musi niejako w Niego wejść z sobą samym, musi sobie ,przyswoić”, zasymilować całą rzeczywistość Wcielenia i Odkupienia, aby siebie odnaleźć. Jeśli dokona się w człowieku ów dogłębny proces, wówczas owocuje on nie tylko uwielbieniem Boga, ale także głębokim zdumieniem nad sobą samym. Jakąż wartość musi mieć w oczach Stwórcy człowiek, skoro zasłużył na takiego i tak potężnego Odkupiciela, skoro

62 Por. J. Cuda, Wiarygodna antropologia, 100-126; J. Cuda, „Prawda ludzkiego życia”, 119-143. Partycypacja jak i ludzka teo-ikoniczność mają charakter relacyjno-wspólnotowy: ja=my, będąc ikoniczną partycypacją w Boskim JA=MY: Ojca, Syna i Ducha Świętego. Boska wartość owej teo-ikonicznej jedyności i niepowtarzalności każdego człowieka jaśnieje ceną Boskiego umiłowania „do końca” i ,wszystko” kenozy i ofiary Chrystusa. 
Bóg „Syna swego Jednorodzonego dał”, ażeby on, człowiek, „nie zginął, ale miał życie wieczne" ${ }^{63}$.

Trójjedyna Miłość, objawiona w posłaniach Jezusa Chrystusa i Ducha Świętego, jawi się zatem jako przyczyna, sens, ukierunkowanie i spełnienie człowieka w jego odniesieniach do samego siebie, innych ludzi i świata. Jest ona zarazem nie tyle zniesieniem jego autopytajności jako samozwrotnej tajemnicy, ile umieszczeniem jej w miłosnym „na zawsze” wewnątrz absolutnej tajemnicy Trójjedynego Boga, czyniąc ją tym samym najpełniej „u siebie”64.

\section{Dziesięć tez trynito-chrysto-logicznie ugruntowanej antropologii}

1. Człowiek jako stworzony „na obraz i podobieństwo” Boga jest capax Dei. Owo teo-ikoniczne capax jest niczym innym, jak podstawą i przeżywaniem - z perspektywy ludzkiej w różnych wymiarach i wydaniach czasowo-świadomościowych - partycypacji w bytowaniu Boga.

2. Zarówno owa partycypacja, jak i ludzka teo-ikoniczność mają charakter relacyjno-wspólnotowy - ja=my - będąc ikoniczną partycypacją w Boskim JA=MY Ojca, Syna i Ducha Świętego. Boska wartość owej teo-ikonicznej jedyności i niepowtarzalności każdego człowieka jaśnieje nieskończoną ceną Boskiego umiłowania, objawionego w „do końca” i ,wszystko” kenozy i ofiary Chrystusa.

3. Stwórczo-zbawcze ukierunkowanie człowieka jawi się jako wolnościowe powołanie do świadomego podjęcia bytowej partycypacji w życiu Trójjedynego Boga i realizacji swego samospełnienia w Chrystusowym Sitz im Leben.

4. Grzech jako wolne zaprzeczenie samospełnieniowemu włączeniu się człowieka w życie Trójcy, zapośredniczanemu przez

${ }^{63} \mathrm{RH}$ nr 10.

64 Por. uwagi G. Greshakego, oparte m.in. na analizach Jörga Splette i Eberharda Jüngela, dotyczące korelacji między tajemnicą a sobością i byciem u siebie, byciem w domu - G. Greshake, Trójjedyny Bóg, 18. 
łaskawo-wolne samodarowanie się Boga, ,wymusza przewidzianą" konieczność zmiany sposobu realizacji ludzkiego powołania, ale nie jego samego.

5. Wydarzenie Chrystusa przywraca człowiekowi możliwość samorealizacji przez spełnieniowe uczestnictwo w naturze Boga jako „syna w Synu”, zarazem objawiając w całej pełni pierwotne powołanie człowieka ukryte od wieków w Bogu i wypełniając je przez nierozerwalne „na zawsze” zjednoczenie człowieczeństwa z bóstwem w Boskiej Osobie Syna w mocy Ducha.

6. W Chrystusie człowiek jako, „syn w Synu” zostaje w pełni i „na zawsze”, choć w medium ,wiary, a nie widzenia” sakramentalności Eklezji w Duchu Świętym, ukierunkowany ku Ojcu, stając się w wierze, nadziei i miłości ,jednym” w „Jednym z Trójcy".

7. Owo ukierunkowanie, będąc ontycznie danym w nowym człowieczeństwie ,wszystkim we wszystkich Chrystusa”, ma charakter na wskroś dynamiczny (co zawarte jest we wschodnio-chrześcijańskim odróżnieniu statyczności „obrazu” i ku-przyszłościowej dynamiczności ,„podobieństwa”), zmierzający do dorastania do pełni Chrystusa.

8. Ostateczne objawienie człowieka samemu człowiekowi, tożsame z jego samospełnieniem, nastąpi w wyniku spotkania człowieka z Ojcem przez Chrystusa w Duchu Świętym „twarzą w twarz”, jako finalnym upodobnieniu przez Boski Archetyp człowieka do samego siebie, przez co Bóg będzie „wszystkim we wszystkich”.

9. Stworzenie zostało w człowieku powołane do nieskończonej epektazy, do nigdy nie kończącego się przekraczania nieskończonej diastemy między absolutnie „Innym” w swej trynitarnej antynomiczności Bogiem a stworzeniem, w kierunku miłosnego meteousia - uczestnictwa „w boskiej naturze” do bycia Bogiem przez łaskę, Bogiem stworzonym „w” i ,z” Bogiem niestworzonym, dokonującego się przez człowieka i w nim w jego nieskończonym podążaniu od bycia ,na obraz Boży” w kierunku ,podobieństwa”. Stąd wszelkie ostateczne i wyczerpujące systematycznie ujęcie bytowości człowieka 
jest w chrześcijaństwie apofatycznie dekonstruowane w wyniku ukrycia tajemnicy człowieczeństwa z Chrystusem w tajemnicy trójjedynego Boga, jako potencjalnie otwartego infinitywnego przychodzenia człowieka do samego siebie w intratrynitarnej nieskończoności Boga.

10. Człowiek w swej apofatycznej misteryjności jest synowskim (,syn w Synu”) - stworzonym, a nie zrodzonym - wydarzeniem w intratrynitarności Boga, usytuowanym w zapośredniczeniu czasowo-historycznym eschatycznie w Chrystusowym byciu z/od Ojca ku/dla Ojcu w Duchu Świętym.

\section{Bibliografia}

Augustyn z Hippony, Wyznania, Z. Kubiak (tłum.), Kraków 2009.

Balthasar, H.U. von, Theodramatik IV, Einsiedeln 1983.

Balthasar, H.U. von, Theologik, B. III: Der Geist der Wahrheit, Einsiedeln 1987. Breviarium Fidei. Wybór doktrynalnych wypowiedzi Kościoła, S. Głowa, I. Bieda (opr.), Poznań 2001.

Bujak, J., Człowiek jako imago Dei. Wokół antropologicznych treści w wybranych dokumentach dialogów doktrynalnych, Szczecin 2007.

Bujak, J., „Czy istnieje możliwość opracowania antropologii wspólnej dla wszystkich chrześcijan?", Roczniki Teologii Ekumenicznej (2009) nr 1, 49-76.

Congar, Y., Wierzę w Ducha Świętego, t. III, L. Rutowska (tłum.), Warszawa 1996.

Cuda, J., „Prawda ludzkiego życia: JA=MY=BÓG”, Śląskie Studia Teologiczno-Historyczne 12 (1979), 119-143.

Cuda, J., Wiarygodna antropologia. Hermeneutyczny zarys teologii fundamentalnej, Katowice 2002.

Dokumenty Soborów Powszechnych, t. II, A. Baron, H. Pietras (red.), Kraków 2002.

Drączkowski, F., Miłość synteza chrześcijaństwa, Lublin 1991.

Dupuis, J., Chrześcijaństwo i religie. Od konfrontacji do dialogu, S. Obirek (tłum.), Kraków 2003.

Dzidek, T., Granice rozumu w teologicznym poznaniu Boga, Kraków 2001.

Florenski, P., Filar i podpora prawdy, J. Chmielewski (tłum.), Warszawa 2009.

Forte, B., Trójca Święta jako historia. Esej o Bogu chrześcijan, A. Rybińska (tłum.), Kraków 2005.

Franciszek, Encyklika Lumen fidei, Kraków 2013.

Greshake, G., Trójjedyny Bóg. Teologia trynitarna, J. Tyrawa (tłum.), Wrocław 2009. 
Greshake, G., Wierzę w Boga Trójjedynego. Klucz do zrozumienia Trójcy Świętej, W. Szymona (tłum.), Kraków 2001.

Greshake, G., Życie silniejsze niż śmierć. O nadziei chrześcijańskiej, J. Kubaszczyk (tłum.), Kraków 2010.

Gryz, K., Antropologia przebóstwienia. Obraz człowieka w teologii prawostawnej, Kraków 2009.

Hemmerle, K., Glauben - wie geht das?, Freiburg i. Br. 1978.

Hemmerle, K., Tezy ontologii trynitarnej, L. Skolik (tłum.), Kielce 2003.

Hryniewicz, W., Chrystus nasza Pascha. Zarys chrześcijańskiej teologii paschalnej, t. 1, Lublin 1987.

Jan od Krzyża, Dzieła, B. Smyrak (tłum.), wyd. 4., Kraków 1998.

Jan Paweł II, Encyklika Fides et ratio, Wrocław 1998.

Jan Paweł II, Encyklika Redemptor hominis, Poznań 1979.

Jan Paweł II, Encyklika Veritatis splendor, Wrocław 1998.

Jan Paweł II, List apostolski Novo millennio ineunte, Wrocław 2001.

Kasper, W., Bóg Jezusa Chrystusa, J. Tyrawa (tłum.), Wrocław 1996.

Kasper, W., Miłosierdzie. Klucz do chrześcijańskiego życia, R. Zajączkowski (tłum.), Poznań 2014.

Kant, I., Streit der Fakultäten, Hamburg 2005.

Katechizm Kościoła Katolickiego, wyd. 2. popr., Poznań 2009.

Katholischer Erwachsenen-Katechismus, Band 1: Das Glaubensbekenntnis der Kirche, http://www.alt.dbk.de/katechismus (dostęp 10.08.2021).

Kehl, M., I widział Bóg, że to jest dobre. Teologia stworzenia, W. Szymona (tłum.), Poznań 2008.

Kongregacja Nauki Wiary, Deklaracja Dominus Iesus o jedyności i powszechności zbawczej Jezusa Chrystusa i Kościoła, Poznań 2000.

Krill, P., Life in Trinity: The Catholic Vision of Communion and Deification, b.m. 2010.

Królikowski, J., Trójca Święta i życie chrześcijańskie, Tarnów 1999.

Liszka, P., Analogia w teologii końca XX wieku, https://documen.site/download/ prof-dr-hab-piotr-liszka-cmf_pdf (dostęp 27.10.2021).

Lubac, H. de, Ateizm i sens człowieka, O. Scherer (tłum.), Paryż 1969.

Lubac, H. de, Dramat humanizmu ateistycznego, A. Ziernicki (tłum.), Kraków 2004.

Łosski, W., Teologia mistyczna Kościoła Wschodniego, I. Brzeska (tłum.), Kraków 2007.

Manikowski, M., „Ekstasis i epektasis jako dwa elementy opisujące doświadczenie mistyczne według Grzegorza z Nyssy”, Filozofia chrześcijańska 14 (2017), 71-86.

Mello, A. de, Przebudzenie, B. Moderska, T. Zysk (tłum.), Poznań 2011.

Międzynarodowa Komisja Teologiczna, Teologia, chrystologia, antropologia, J. Bielecki (tłum.), w: Od wiary do teologii. Dokumenty Międzynarodowej 
Komisji Teologicznej 1969-1996, J. Królikowski (red.), Kraków 2000, $133-150$.

Misztal, W., Duchowość chrześcijan w świetle listów Pawłowych, Kraków 2010. Od bogów pogańskich do Boga żywego. Z prof. Anna Świderkówna rozmawia Włodzimierz Zatorski, wyd. 2., Kraków 2007.

Od „śmierci Boga" do „śmierci człowieka”: rodowody, konteksty, destrukcje we wspótczesnej myśli filozoficznej, J. Krasicki, S. Kijaczko (red.), Opole 2001. Papieska Rada ds. Krzewienia Nowej Ewangelizacji, Żyć rokiem wiary. Program duszpasterski, M. Masny (tłum.), Częstochowa 2012.

Philipon, M.M., Trójca Święta w moim życiu. Doktryna duchowa Siostry Elżbiety od Trójcy Przenajświętszej, siostra benedyktynka od nieustającej adoracji (tłum.), Poznań 2002.

Piotrowski, E., Traktat o Trójcy Świętej, w: E. Adamiak, A. Czaja, J. Majewski (red.) Dogmatyka, t. 4, Warszawa 2007, 15-319.

Płóciennik, M., „Państwo Boże w relacji do Kościoła i świata w De civitate Dei św. Augustyna (księgi 11-22). Teologiczno-filozoficzne refleksje na gruncie chrześcijańskiej historiozofii”, Prace Naukowe Akademii im. Jana Dlugosza w Częstochowie: Filozofia (2015) z. XII, 41-74.

„Przepowiadanie Trójjedynego Boga. Rozmowa z abp. Józefem Życińskim, metropolitą lubelskim", Teofil (2004) 2, 17-27.

Rahner, K., „Doświadczenia katolickiego teologa”, T. Węcławski (tłum.), Znak 2 (1992) 2, 72-82.

Rahner, K., O specyfice chrześcijańskiego pojęcia Boga, w: K. Rahner, Pisma wybrane, t. 1, G. Bubel (wybór i tłum.), Kraków 2005, 157-167.

Ratzinger, J., „Was ist für den christlichen Glauben konstitutiv?”, w: H. Rossmann, J. Ratzinger (red.), Mysterium der Gnade. Festschrift für Johann Auer zum 65. Geburtstag, Regensburg 1975, 11-19.

Scheffczyk, L., Uneingelöste Traditionen der Trinitätslehre, w: Trinität. Aktuelle Perspektiven der Theologie (Quaestiones disputatae 101), W. Breuning (red.), Freiburg - Basel - Wien 1984, 47-72.

Scola, A., Marengo, G., López, J.P., Osoba ludzka. Antropologia teologiczna, L. Balter (tłum.), Poznań 2005.

Składanowski, M., Niewiele mniejszy od aniołów. Wspólne chrześcijańskie świadectwo o człowieku, Lublin 2014.

Sobór Watykański II. Konstytucje, Dekrety, Deklaracje, Poznań 2002.

Strzelczyk, G., Teraz Jezus, Warszawa 2007.

Szczerba, W., „Problem przebóstwienia na tle apofatycznej teologii Grzegorza z Nyssy", w: J. Baniak (red.), Filozofia religii. T. 5: Mistyka jako stan świadomości i typ doświadczenia religijnego, Poznań 2005, 283-299.

Varillon, F., Radość wiary, radość życia, M. Książek (tłum.), Kraków 1989. 
Woźniak, R.J., „Chrystocentryzm teologii chrześcijańskiej. Chrystologiczna gramatyka kościelnego wyznania wiary w perspektywie trynitarnej”, Analecta Cracoviensia 38-39 (2006-2007), 367-394.

Woźniak, R.J., Przyszłość, teologia, społeczeństwo, Kraków 2007.

Woźniak, R.J., Metafizyka i Trójca. Teo-ontologia trynitarna pomiędzy apofatyka i katafatyka, w: R.J. Woźniak (red.), Metafizyka i teologia. Debata u podstaw, Kraków 2008, 270-304.

\title{
Intratrinitarity of God as the Revealed Hermeneutic Key of Christian Truthfulness Anthropology
}

\begin{abstract}
The triunity of God is the essence of the most important Christian dogma, being the hermeneutic key of the experience of the Revelation and of the history of salvation. It constitutes the one, and in fact the only, Truth of many truths of the faith. The experience that constitutes Christianity is thus the radical and definitive self-granting of the Triune God: Pater per Filium in Spiritu Sancto. Therefore, the understanding of who the Triune God really is constitutes the inevitable Christiantruthful condition of any possible hermeneutics. It is not merely some fascinating speculation, but rather 'to be or not to be' of Christianity, and hence 'to be or not to be' of humankind in its entire created reality as the proper recipient of the selfgranting of God. The mystery of every human person, both in his/her individual and his/her social dimension, is in the Christian perspective given to be understood only as happening between the Father, the Son, and the Holy Spirit.
\end{abstract}

Keywords: Holy Trinity, theological anthropology, Trinitarian hermeneutics, selfgranting of God 